\title{
EFEK PENGERINGAN PADA BAGIAN BUAH LABU KUNING (CUCURBITA MOSCHATA) TERHADAP AKTIVITAS ANTIOKSIDAN, SIFAT KIMIA DAN STRUKTUR MORFOLOGI
}

\section{THE EFFECT OF DRYING METHODS ON ANTIOXIDANT ACTIVITY, CHEMICAL PROPERTIES AND MORPHOLOGICAL STRUCTURE OF PUMPKIN (CUCURBITA MOSCHATA)}

\author{
Anastasia Wheni Indrianingsih, Wuri Apriyana, Vita Taufika Rosyida, \\ Khoirun Nisa, Septi Nurhayati, Cici Darsih \\ Balai Penelitian Teknologi Bahan Alam, Lembaga Ilmu Pengetahuan Indonesia \\ Jl. Wonosari Km 31,5, Gading, Playen, Gunungkidul, Yogyakarta, Indonesia 55861 \\ Email : anastasia.wheni.i@gmail.com / anas004@lipi.go.id
}

Diterima : 12-12-2018

Direvisi : 28-01-2019

Disetujui : 19-02-2019

\begin{abstract}
ABSTRAK
Labu kuning (C. moschata) merupakan salah satu tanaman yang banyak terdapat di Indonesia. Penelitian ini bertujuan untuk mempelajari aktivitas antioksidan, struktur morfologi, dan sifat kimia dari tiga komponen tepung yakni kulit, biji dan daging buah dari labu kuning. Ekstrak biji, kulit dan daging buah labu kuning diperoleh dengan maserasi menggunakan pelarut etanol. Dua metode pengeringan yang digunakan yakni pengeringan dengan sinar matahari dan oven pada suhu $50^{\circ} \mathrm{C}$. Hasil uji aktivitas antioksidan dengan metode DPPH (2,2-diphenyl-1-picrylhydrazyl) menunjukkan bahwa biji labu kuning dengan metode pengeringan oven, memiliki aktivitas antioksidan yang paling tinggi, yakni memiliki aktivitas penangkapan radikal bebas sebesar $22,6 \%$ pada konsentrasi ekstrak $400 \mathrm{ppm}$, diikuti oleh kulit dan daging buah labu kuning masing-masing sebesar 16,7 dan 14,2\%. Tepung kulit, biji dan daging buah labu kuning juga sudah dilakukan karakterisasi menggunakan SEM (Scanning Electron Microscopy) untuk mengetahui struktur morfologi permukaan, FTIR ( Fourier Transform Infrared Spectroscopy) untuk mengetahui gugus fungsional senyawa dari labu kuning, XRD (X-ray diffraction) dan Uji Warna. Hasil analisis proksimat menunjukkan bahwa kandungan protein dan lemak dari biji labu kuning dengan metode pengeringan oven memiliki kandungan paling tinggi yakni sebesar 33,5\% dan 33,3\% sedangkan kandungan karbohidrat tertinggi dimiliki oleh daging buah labu kuning dengan pengeringan oven sebesar 75,3\%. Data dianalisis menggunakan program SPSS yang dilanjutkan dengan tes Duncan. Derajat kepercayaan pada level $95 \%$ dan perbedaan pada taraf $<5 \%$ tidak berbeda nyata. Setiap analisis dilakukan dengan 3 kali ulangan. Hasil yang diperoleh menunjukkan bahwa perbedaan metode pengeringan menghasilkan karakteristik yang berbeda dari tepung labu kuning.
\end{abstract}

Kata kunci : C. moschata, antioksidan, pengeringan, DPPH

\begin{abstract}
This study aims to examine the antioxidant activity, morphological structure, and chemical properties of Cucurbita moschata (pumpkin). The three examined components of $C$. moschata were rinds, seeds and pulp of the pumpkin. The extracts were obtained by maceration using ethanol. The two drying methods used were conventional drying method using sunlight and oven drying method at $50^{\circ} \mathrm{C}$. The results of the antioxidant activity test using the DPPH (2,2-diphenyl-1-picrylhydrazyl) method showed that seeds with oven drying method had the highest antioxidant activity, which had a free radical antioxidant activity of $22.6 \%$ at concentration of 400 ppm followed by rinds and pulp of $16.7 \%$ and $14.2 \%$, respectively. Characterization of flour, seeds and pulp of pumpkin were conducted using SEM (Scanning Electron Microscopy) to determine the surface morphological structure, Fourier Transform Infrared Spectroscopy to determine the functional groups of pumpkin, XRD (X-ray diffraction) and Color Test. The proximate analysis results showed that the protein and fat content of seeds with oven drying
\end{abstract}


method had the highest content of 33.5\% and 33.3\% while the highest carbohydrate content was obtained in pulp with oven drying as of $75.3 \%$. Data were analyzed using the SPSS program followed by the Duncan test. Degree of trust at level $95 \%$ and difference at level $<5 \%$ is not significantly different. Each analysis was carried out with 3 replications. The results obtained showed that the different drying methods produced different characteristics of pumpkin flour.

Keywords: C. moschata, antioxidant, drying, DPPH

\section{PENDAHULUAN}

$\mathrm{R}$ adikal bebas berbahaya bagi tubuh manusia karena bisa menyebabkan reaksi yang oksidatif dan berakhir pada timbulnya berbagai penyakit seperti kanker, diabetes, dan penuaan (Ani et al., 2006). Selain berasal dari lingkungan sekitar seperti asap rokok, paparan senyawa kimia, polusi udara, dan alkohol, beberapa proses kimia di dalam tubuh juga bisa menyebabkan timbulnya senyawa oksigen yang reaktif, seperti radikal superoksida, senyawa hidroksil, dan senyawa radikal peroksil sebagai hasil senyawa samping. Oleh karena itu, senyawa antioksidan sangat penting karena bisa memperlambat proses oksidasi. Senyawa antioksidan juga bisa menghambat pembentukan radikal bebas. Akan tetapi beberapa penelitian menyebutkan bahwa senyawa antioksidan sintetik bisa terakumulasi di tubuh manusia dan menyebabkan penyakit seperti kanker dan kerusakan organ. Hal ini mengindikasikan bahwa penggunaan senyawa antioksidan alami dari tanaman sangat direkomendasikan di industri makanan dan kesehatan untuk alasan keamanan, serta efek nutrisi dan terapiknya (Deng et al., 2011). Buah, sayuran, tanaman herbal dan rempah mengandung berbagai senyawa antioksidan seperti senyawa fenol, nitrogen, vitamin, dan terpenoid (Cai et al., 2003). Karena pentingnya senyawa antioksidan dalam bidang kesehatan, banyak riset yang dilakukan dalam usaha menemukan senyawa antioksidan alami dari tanaman.

C. moschata atau labu kuning merupakan salah satu tanaman yang banyak ditemukan dan ditanam di Indonesia. Banyak kegunaan dari labu kuning karena kandungan nutrisinya yang tinggi, efek pencernaan yang bagus dan karakteristik sensorinya (Noelia, 2011). Daging buah labu kuning biasanya digunakan dalam sup, pie dan pembuatan roti, sedangkan biji labu kuning biasa dikonsumsi sebagai makanan ringan dan bahan farmasetikal. Berdasarkan hal ini, labu kuning sangat potensial untuk dimanfaatkan dalam makanan, kosmetik dan farmasetikal (Quintana et al., 2018). Berdasarkan penerimaan dan industrialisasi produkproduk turunan dari labu kuning yang bagus, informasi dan pengetahuan yang lebih saintifik seperti sifat kimia dan fisikokimia dari labu kuning sangat penting dan diperlukan. Tujuan dari penelitian ini yaitu untuk mengetahui dan membandingkan tentang aktivitas antioksidan, sifat kimia, struktur morfologi permukaan dan grup fungsional dari tepung biji, kulit dan daging buah labu kuning dengan dua metode pengeringan, yaitu dengan cahaya matahari dan oven. Hasil yang diperoleh dari penelitian ini diharapkan dapat menambah pengetahuan dalam pengembangan produk-produk baru dari labu kuning.

\section{BAHAN DAN METODE}

\section{Bahan}

Labu kuning ( $C$. moschata) diperoleh dari daerah Gunungkidul, Yogyakarta pada bulan Juni-Juli 2018. Bahan kimia DPPH, asam askorbat, metanol dan etanol diperoleh dari Sigma Aldrich (Jepang). 


\section{Pembuatan Ekstrak Etanol}

Labu kuning dicuci bersih dan diiris-iris menjadi potongan kecil. Dipisahkan 3 sampel labu kuning yang terdiri dari kulit, biji dan daging buah. Labu kuning kemudian dikeringkan dengan oven pada suhu $50^{\circ} \mathrm{C}$ dan pengeringan dengan sinar matahari langsung sampai diperoleh kadar air dibawah 5\% dan ditepungkan. Ekstrak etanol diperoleh dengan cara melakukan maserasi terhadap tepung biji, kulit dan daging buah labu kuning dengan etanol $(1: 8 \mathrm{~b} / \mathrm{b})$ selama 3 hari pada suhu ruang.

\section{Karakterisasi Tepung Labu Kuning}

Struktur morfologi permukaan labu kuning dianalisis dengan SEM (Hitachi SU-70, Jepang) yang dioperasikan pada 4 kV. Analisis FTIR (8201PC Shimadzu, Jepang) dari tepung labu dilakukan pada panjang gelombang $500-4000 \mathrm{~cm}^{-1}$ dan analisis XRD (Rigaku SmartLab, Jepang) dilakukan pada sudut $2 \Theta 10-80^{\circ}$. Analisis proksimat dilakukan sesuai dengan metode Standar Nasional Indonesia (SNI) 01-2891-1992 (1992).

\section{Uji Warna}

Parameter uji warna dilakukan menggunakan instrumentasi Colour Reader (CR 20 Colour Reader Konica Minolta). Hasil yang diperoleh diwujudkan dalam bentuk $L^{*}$, $a *$ dan $b^{*}$, dengan $\mathrm{L}$ (lightness) merupakan tingkat kecerahan yang berkisar antara hitam (0) dan putih (100), a* berkisar antara hijau $(-60)$ ke merah $(60)$ dan $b^{*}$ berkisar antaran biru $(-60)$ ke kuning $(60)$.

\section{Uji DPPH}

Ekstrak labu kuning dilarutkan dalam metanol dalam berbagai konsentrasi dan direaksikan dengan DPPH (1,01 mM) pada suhu ruang. Larutan tersebut didiamkan selama 30 menit dalam kondisi gelap. Absorbansi diukur menggunakan Elisa Reader pada panjang gelombang $517 \mathrm{~nm}$. Penangkapan radikal bebas dihitung dengan persamaan 1:

Akivitas penangkapan radikal DPPH $(\%)=\left(\frac{\mathrm{A} 0-\mathrm{A} 1}{\mathrm{~A} 0} \times 100\right)$

Dimana $\mathrm{A}_{0}$ : absorbansi kontrol, $\mathrm{A}_{1}$ : absorbansi sampel. Penangkapan radikal bebas DPPH dilakukan dengan tiga kali ulangan.

\section{Analisis Statistik}

Data dianalisis menggunakan program SPSS yang dilanjutkan dengan tes Duncan. Derajat kepercayaan pada level $95 \%$ dan perbedaan pada taraf $<5 \%$ tidak berbeda nyata. Setiap analisis dilakukan dengan 3 kali ulangan.

\section{HASIL DAN PEMBAHASAN}

\section{Komposisi Proksimat Tepung Labu Kuning}

Pengeringan merupakan suatu cara untuk mengurangi kadar air suatu bahan sehingga diperoleh bahan dengan kondisi akhir yang kering. Beberapa faktor untuk memperoleh proses pengeringan yang maksimal yaitu luas permukaan sampel, kecepatan udara, suhu, kelembaban udara, tekanan atmosfir dan waktu. Hasil analisis proksimat tepung labu kuning berupa biji, kulit dan daging buah ditampilkan di Tabel 1. Dalam proses pengeringan dengan menggunakan oven, salah satu keunggulannya yaitu prosesnya yang lebih cepat dan lebih terukur, sedangkan dengan proses pengeringan sinar matahari, keunggulannya yaitu biaya yang murah namun memiliki kelemahan prosesnya lebih lambat sehingga memerlukan waktu yang lebih lama, tergantung pada keadaan cuaca dan hasil proses pengeringan kurang maksimal. 
Tabel 1. Komposisi Kimia Tepung Labu

\begin{tabular}{lccccccc}
\hline Sampel & $\begin{array}{c}\text { Air } \\
(\%)\end{array}$ & $\begin{array}{c}\text { Abu } \\
(\%)\end{array}$ & $\begin{array}{c}\text { Protein } \\
(\%)\end{array}$ & $\begin{array}{c}\text { Lemak } \\
(\%)\end{array}$ & $\begin{array}{c}\text { Karbohidrat } \\
(\%)\end{array}$ & $\begin{array}{c}\text { Energi } \\
(\mathrm{kal} / 100 \mathrm{~g})\end{array}$ & $\begin{array}{c}\text { Metode } \\
\text { pengeringan }\end{array}$ \\
\hline Biji & $7,1 \pm 0,4^{\mathrm{b}}$ & $4,4 \pm 0,1^{\mathrm{a}}$ & $23,2 \pm 1,1^{\mathrm{e}}$ & $23,5 \pm 1,1^{\mathrm{e}}$ & $41,5 \pm 1,5^{\mathrm{b}}$ & $472,4 \pm 10,2^{\mathrm{e}}$ & Matahari \\
Kulit & $11,3 \pm 0,8^{\mathrm{e}}$ & $7,2 \pm 0,2^{\mathrm{d}}$ & $11,5 \pm 0,9^{\mathrm{c}}$ & $1,5 \pm 0,04^{\mathrm{a}}$ & $68,4 \pm 2,33^{\mathrm{c}, \mathrm{d}}$ & $326,2 \pm 9,8^{\mathrm{b}}$ & Matahari \\
Daging & $11,6 \pm 0,9^{\mathrm{f}}$ & $10,9 \pm 0,7^{\mathrm{e}}$ & $8,9 \pm 0,3^{\mathrm{b}}$ & $1,7 \pm 0,02^{\mathrm{b}}$ & $66,8 \pm 2,1^{\mathrm{c}}$ & $311,5 \pm 9,4^{\mathrm{a}}$ & Matahari \\
Biji & $4,2 \pm 0,1^{\mathrm{a}}$ & $5,2 \pm 0,1^{\mathrm{b}}$ & $33,5 \pm 1,2^{\mathrm{f}}$ & $33,3 \pm 1,3^{\mathrm{f}}$ & $23,5 \pm 0,12^{\mathrm{a}}$ & $535,9 \pm 10,6^{\mathrm{f}}$ & Oven \\
Kulit & $7,4 \pm 0,2^{\mathrm{c}}$ & $4,4 \pm 0,1^{\mathrm{a}}$ & $13,4 \pm 0,9^{\mathrm{d}}$ & $5,6 \pm 0,3^{\mathrm{d}}$ & $69,6 \pm 2,2^{\mathrm{d}}$ & $374,5 \pm 9,3^{\mathrm{d}}$ & Oven \\
Daging & $9,1 \pm 0,5^{\mathrm{d}}$ & $6,5 \pm 0,2^{\mathrm{c}}$ & $5,8 \pm 0,2^{\mathrm{a}}$ & $3,2 \pm 0,09^{\mathrm{c}}$ & $75,3 \pm 2,5^{\mathrm{e}}$ & $343,8 \pm 8,9^{\mathrm{c}}$ & Oven \\
\hline
\end{tabular}

Keterangan: Perbedaan huruf pada hasil analisis menunjukkan perbedaan yang signifikan pada derajat kepercayaan pada level 95\%. Setiap analisis dilakukan dengan 3x ulangan.

Data yang diperoleh mengindikasikan bahwa biji labu kuning dengan pengeringan menggunakan oven mengandung protein dan lemak yang lebih tinggi yakni sebesar 33,5 dan $33,3 \%$ sedangkan biji labu kuning dengan pengeringan sinar matahari langsung memiliki kandungan protein dan lemak sebesar 23,2 dan 23,5\%. Secara garis besar, biji labu kuning memiliki kandungan protein dan lemak yang paling besar dibandingkan kulit dan daging buah. Kandungan karbohidrat yang paling tinggi, terdapat pada daging buah dengan pengeringan oven, yakni sebesar $75,3 \%$ yang diikuti oleh kulit dengan pengeringan oven sebesar $69,6 \%$ dan kulit dengan pengeringan sinar matahari langsung sebesar $68,4 \%$. Penelitian yang lain menunjukkan bahwa karena aktivitas air yang rendah, tepung labu memiliki kualitas dan masa simpan yang lama (Aziah dan Komathi, 2009).

\section{Struktur Morfologi Tepung Labu Kuning}

Struktur morfologi permukaan dari tepung labu kuning (biji, kulit, daging) yang dihasilkan dari dua metode pengeringan oven dan sinar matahari dianalisis dengan menggunakan SEM dengan perbesaran sebesar 10.000x. Gambar 1 menunjukkan struktur permukaan dari tepung labu kuning.

(a)

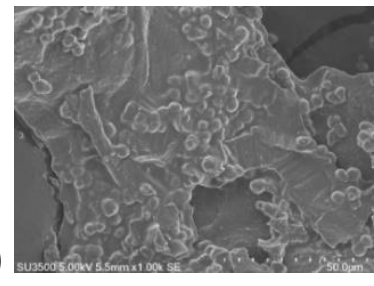

(d)

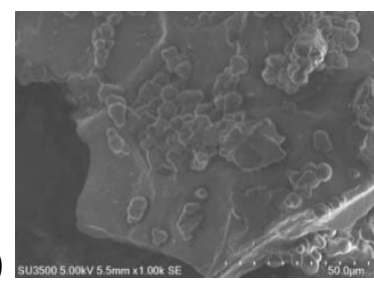

(b)



(e)

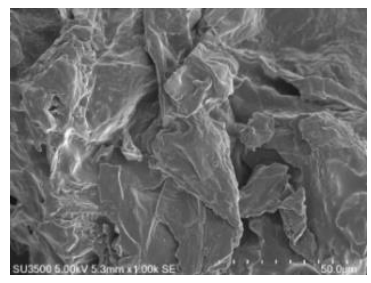

(c)

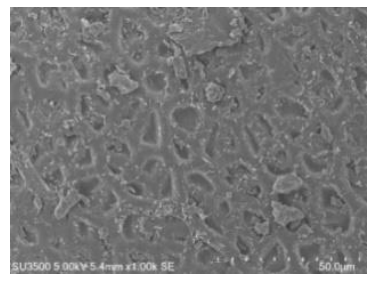

(f)

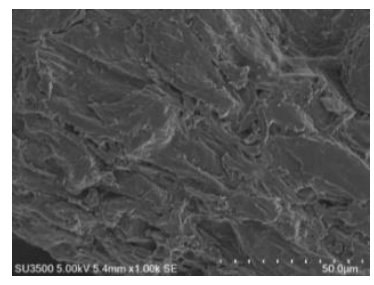

Gambar 1. Struktur SEM Dari Labu Kuning dengan Metode Pengeringan Matahari: (a) Biji, (b) Daging, (c) Kulit; dan Metode Pengeringan Oven: (d) Biji, (e) Daging, (f) Kulit. 
SEM dari biji, kulit dan daging buah labu kuning ditunjukkan pada Gambar 1. Mikrogram dari tepung labu kuning menunjukkan bahwa permukaan labu kuning sangat kompak dan kasar. Struktur yang kompak kemungkinan dipengaruhi oleh ikatan kompleks lemak dan protein (Nakhon, 2017).

\section{Struktur difraktogram XRD tepung labu kuning}

Analisis XRD digunakan untuk mengetahui struktur kristalin dari pati yang terkandung dalam suatu tanaman. Pati dari sumber tanaman yang berbeda menunjukkan struktur difraktogram yang berbeda pula (Wani et al., 2015).

(a)



(b)

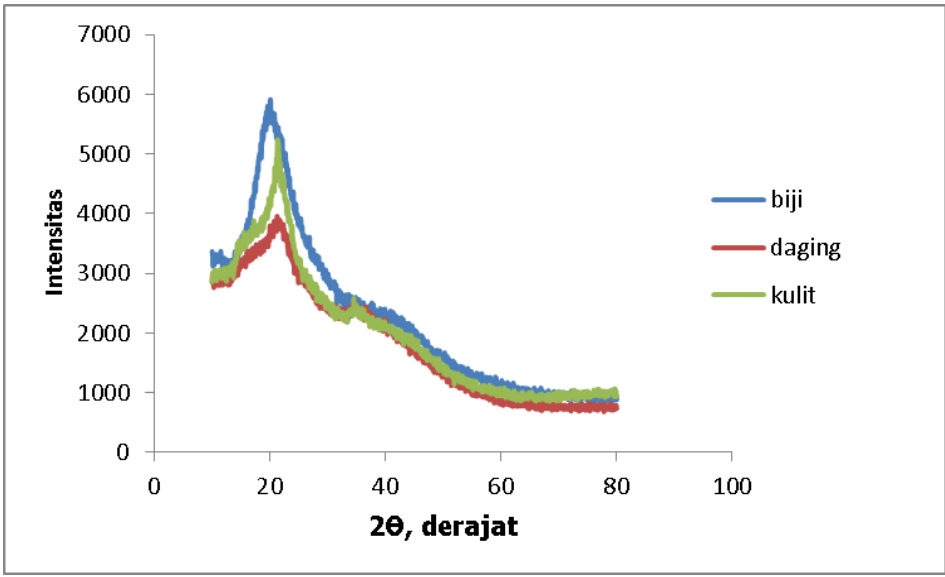

Gambar 2. Difraktogram Dari Tepung Labu Kuning (Biji, Daging Dan Kulit) Dengan Metode Pengeringan (a) Sinar Matahari Langsung, dan (b) Oven. Proses Analisis Menggunakan XRD (Smartlab Rigaku, Jepang pada parameter $2 \theta 10-80^{\circ}$ )

Dari gambar 2 terlihat bahwa struktur difraktogram labu kuning memiliki struktur yang amorf. Beberapa literatur menyebutkan bahwa pati dari labu kuning memiliki sudut difraksi pada $15^{\circ}, 18^{\circ}, 20^{\circ}$ dan $23^{\circ}$ (Wani et al., 2015). Tingkat kristalinitas dari pati tanaman bervariasi sesuai dengan kandungan amilopektin dan ukuran kristal (Jan et al., 2016).

\section{Uji warna dan aktivitas antioksidan}

Warna merupakan salah satu parameter penting di dalam penerimaan produk pangan oleh konsumen. Tabel 2 menunjukkan uji warna dan aktivitas antioksidan dari tepung biji, kulit dan daging buah labu kuning dengan metode pengeringan sinar matahari langsung dan oven. 
Tabel 2. Parameter Warna ( $\left.L^{*}, a^{*}, b^{*}\right)$ dan Aktivitas Antioksidan dari Biji, Kulit dan Daging Buah Labu Kuning dengan Metode Pengeringan Sinar Matahari dan Oven

\begin{tabular}{|c|c|c|c|c|c|}
\hline & $L^{*}$ & a* & $b^{*}$ & $\begin{array}{c}\text { Aktivitas } \\
\text { penangkapan } \\
\text { radikal bebas (\%) } \\
\text { pada konsentrasi } \\
400 \mathrm{ppm}\end{array}$ & $\begin{array}{c}\text { Metode } \\
\text { pengeringan }\end{array}$ \\
\hline Biji & $65,3 \pm 0,5^{b}$ & $1,9 \pm 0,1^{\mathrm{a}}$ & $20,8 \pm 0,5^{a}$ & $19,5 \pm 0,9^{\mathrm{e}}$ & Matahari \\
\hline Daging buah & $68,6 \pm 0,5^{c}$ & $7,8 \pm 0,3^{c}$ & $27,8 \pm 0,4^{b}$ & $8,5 \pm 0,7^{b}$ & Matahari \\
\hline Kulit & $66,4 \pm 0,2^{b}$ & $4,3 \pm 0,1^{b}$ & $19,5 \pm 0,3^{a}$ & $11,3 \pm 0,4^{a}$ & Matahari \\
\hline Biji & $54,5 \pm 0,4^{a}$ & $7,4 \pm 0,1^{c}$ & $28,0 \pm 0,2^{b}$ & $22,6 \pm 1,2^{f}$ & Oven \\
\hline Daging buah & $65,1 \pm 0,2^{b}$ & $16,7 \pm 0,4^{d}$ & $46,4 \pm 0,6^{c}$ & $14,2 \pm 0,8^{d}$ & Oven \\
\hline Kulit & $65,5 \pm 0,4^{b}$ & $7,4 \pm 0,1^{c}$ & $28,0 \pm 0,2^{b}$ & $16,7 \pm 0,9^{c}$ & Oven \\
\hline
\end{tabular}

Keterangan: Perbedaan huruf pada hasil analisis menunjukkan perbedaan yang signifikan pada derajat kepercayaan pada level $95 \%$. Setiap analisis dilakukan dengan 3x ulangan.

Pada hasil ini, tingginya nilai $b^{*}$ dikorelasikan dengan warna kekuningan dari tepung labu kuning. Pada tepung labu kuning dengan pengeringan menggunakan sinar matahari langsung, diperoleh nilai $b^{*}$ pada kisaran antara 19,5 sampai 27,8, dengan warna yang mendekati paling kuning adalah daging buah. Pada pengeringan dengan metode oven, diperoleh nilai $b^{*}$ pada kisaran antara 28,0 dan 46,4 , dengan warna yang paling mendekati paling kuning juga merupakan daging buah. Untuk nilai kecerahan $\left(L^{*}\right)$, daging buah dengan pengeringan sinar matahari memiliki tingkat kecerahan paling tinggi sebesar 68,6.

Dari Tabel 2 dapat dilihat bahwa aktivitas penangkapan radikal bebas dari ekstrak tepung labu kuning (biji, kulit dan daging buah) berada pada kisaran antara 8,5-19,5 \% untuk tepung dengan pengeringan matahari, dan antara 14,2-22,6\% untuk tepung dengan pengeringan oven. Asam askorbat yang dijadikan standar positif untuk uji ini memiliki aktivas penangkapan radikal bebas sekitar $89,1 \%$ pada konsentrasi 200 ppm. Baik dengan pengeringan sinar matahari langsung maupun dengan pengeringan oven, ekstrak biji labu kuning memiliki aktivitas penangkapan radikal yang paling tinggi, yakni sebesar $19,5 \%$ untuk pengeringan dengan matahari dan $22,6 \%$ dengan pengeringan oven, yang diikuti dengan ekstrak kulit dan ekstrak daging buah. Ekstrak kulit, biji dan daging buah labu kuning ini memiliki kemampuan aktivitas antioksidan yang berbeda kemungkinan disebabkan adanya perbedaan kandungan senyawa dalam kulit, biji maupun daging buah labu kuning yang berbeda.

Hasil aktivitas antioksidan di atas menunjukkan bahwa biji labu kuning memiliki potensi yang sangat tinggi untuk dikembangkan sebagai produk makanan maupun nutrasetikal. Biji labu kuning hanya merupakan limbah pertanian dan ini sangat disayangkan, sedangkan beberapa negara mengonsumsi biji labu kuning ini dalam skala rumah tangga (Patel, 2013). Beberapa senyawa fenolik dan tokoferol yang kaya akan protein, lemak dan aktivitas antioksidan tinggi terdapat dalam biji labu kuning (Jorge et al., 2015). Biji labu kuning juga digunakan sebagai obat tradisional karena kemampuan antibakteri, dan antidiabetesnya (Yadav et al., 2010). Studi yang lain juga menunjukkan bahwa konsumsi biji labu kuning bisa mencegah penyakit pada prostat (Nkosi et al., 2006). Beberapa literatur menyebutkan bahwa senyawa aktif seperti morin dan katekin terdapat dalam labu kuning (Rocha-Guzman et al., 2012).

\section{Spektra Inframerah (FTIR) tepung labu kuning}

Spektra inframerah digunakan sebagai salah satu metode analisis kimia untuk mengetahui gugus fungsional yang terdapat dalam suatu bahan. Dalam industri makanan, metode pengujian FIIR ini juga biasanya digunakan dalam kontrol monitoring kualitas suatu

38 Anastasia Wheni Indrianingsih, Wuri Apriyana, Vita Taufika Rosyida, Khoirun Nisa, Septi Nurhayati, Cici Darsih 
komponen kimia dalam sampel dengan cepat. Gambar 3 menunjukkan spektra inframerah dari tepung labu kuning (biji, kulit dan daging buah) dengan metode pengeringan sinar matahari langsung dan oven.

(a)

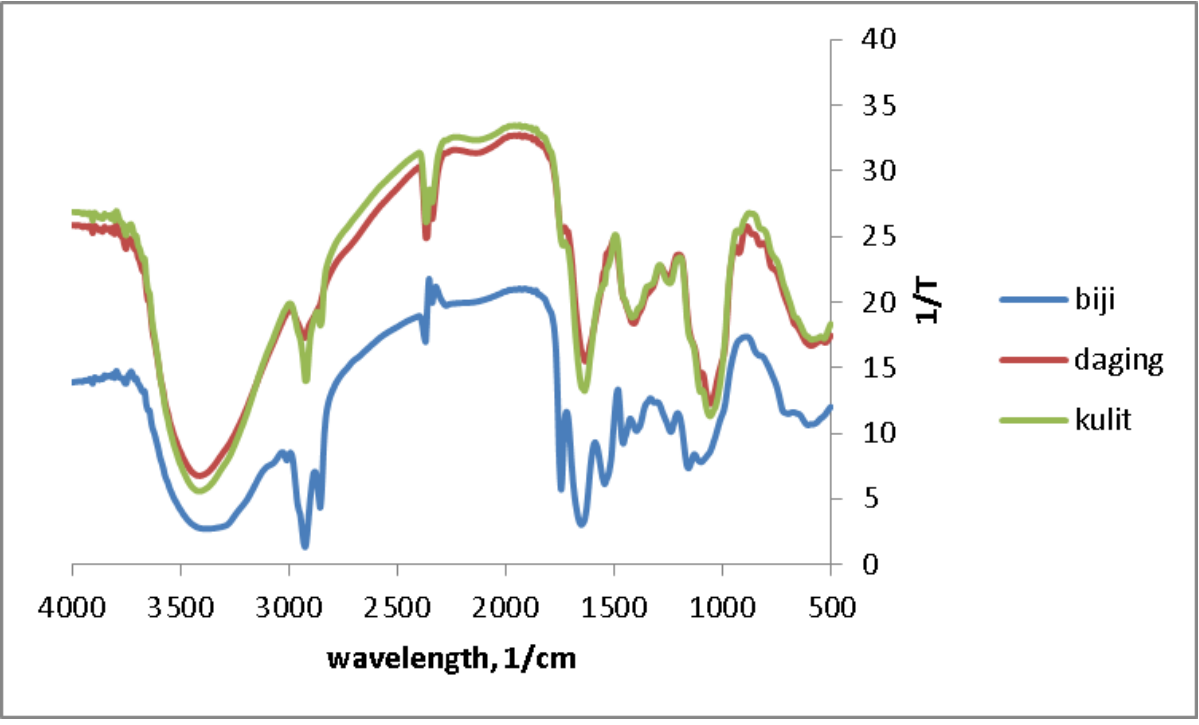

(b)

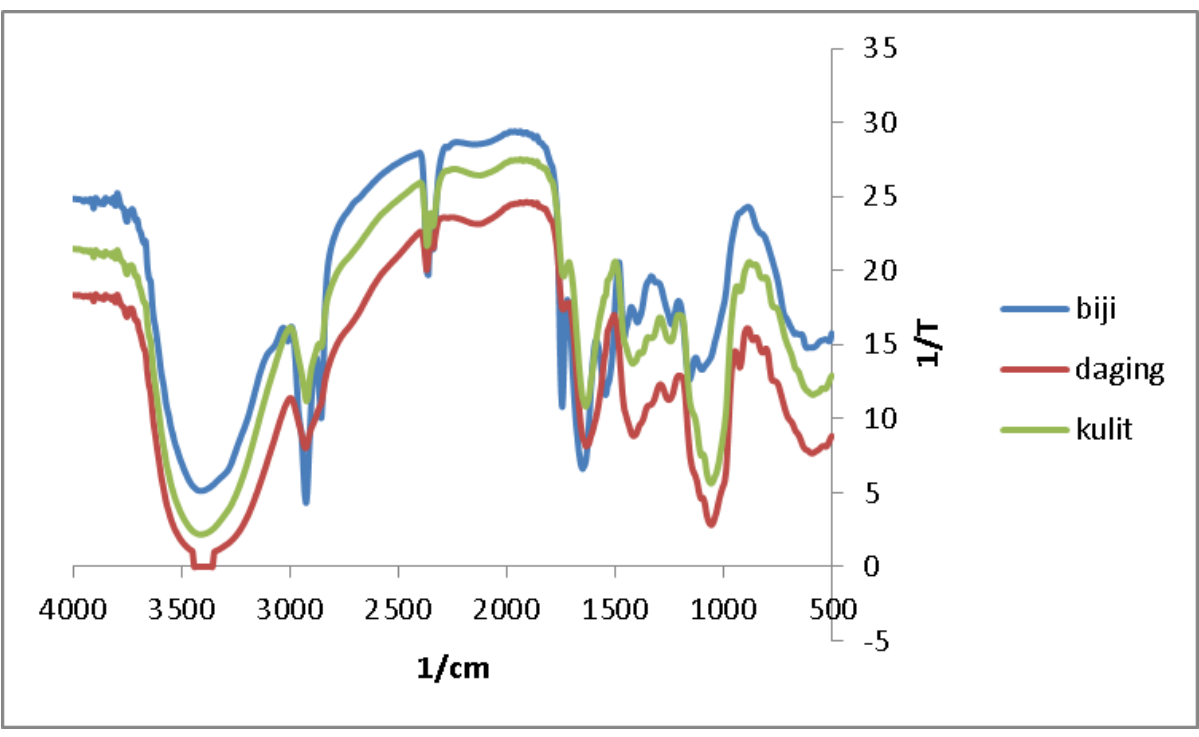

Gambar 3. Spektra FTIR Tepung Labu Kuning (Biji, Daging Buah Dan Kulit) dengan Metode Pengeringan (a) Sinar Matahari Langsung (b) Oven Pada Panjang Gelombang $500-4000 \mathrm{~cm}^{-1}$.

Seperti dapat dilihat pada Gambar 3, spektra inframerah tepung labu kuning dianalisis pada frekuensi antara 4000-500 $\mathrm{cm}^{-1}$. Serapan pada panjang gelombang sekitar 3455-3245 $\mathrm{cm}^{-1}$ pada umumnya merupakan gugus fungsi hidroksil $(\mathrm{OH})$ dari karbohidrat atau senyawa lainnya seperti asam karboksilat dan keton. Sedangkan serapan pada sekitar $2940-2855 \mathrm{~cm}^{-1}$ berkorelasi dengan adanya serapan $\mathrm{CH}$. Pada panjang gelombang sekitar $3118-3025 \mathrm{~cm}-1$ sering dikorelasikan dengan adanya gugus fungsi dari amida $(\mathrm{NH})$ dan serapan pada 1104$1011 \mathrm{~cm}^{-1}$ dikorelasikan dengan adanya lemak.

\section{KESIMPULAN}


Aktivitas antioksidan tepung labu kuning dengan metode pengeringan oven, memiliki sifat fisikokimia dan aktivitas antioksidan yang lebih baik dibandingkan dengan metode pengeringan menggunakan sinar matahari langsung. Aktivitas antioksidan biji labu kuning dengan metode pengeringan oven merupakan yang paling tinggi yakni sebesar $22,6 \%$ pada konsentrasi ekstrak 400 ppm. Penelitian ini menunjukkan bahwa semua bagian labu kuning baik kulit, biji maupun daging buah memiliki potensi yang sangat besar untuk dikembangkan sebagai makanan dan nutrasetikal.

\section{UCAPAN TERIMA KASIH}

Terima kasih penulis sampaikan kepada Kementrian Ristek, Teknologi dan Pendidikan Tinggi Republik Indonesia (Kemenristekdikti) untuk pembiayaan penelitian ini melalui program Insinas No. 022/P/RPL-LIPI/INSINAS-II/VII/2018.

\section{DAFTAR PUSTAKA}

[BSN] Badan Standardisasi Nasional. 1992. (SNI) 01-2891-1992: Cara Uji Makanan dan Minuman, Jakarta: Badan Standarisasi Nasional.

Ani, V., M.C. Varadaraj, dan K.A. Naidu. (2006). Antioxidant and antibacterial activities of polyphenolic compounds from bitter cumin (Cuminumnigrum L.). European Food Research Technology 224:109-115.

Aziah, A. A. N. dan C.A. Komathi. 2009. Physicochemical and functional properties of peeled and unpeeled pumpkin flour. Journal of Food Science 74: S328-S333.

Cai, Y.Z., M. Sun , dan H. Corke. 2003. Antioxidant activity of betalains from plants of the Amaranthaceae. Journal of Agricultural and Food Chemistry 51: 2288-2294.

Deng, J., W. Cheng, dan G. Yang. 2011. A novel antioxidant activity index (AAU) for natural products using the DPPH assay. Food Chemistry 125: $1430-1435$.

Jan, R., D.C. Saxena, S. Singh. 2016. Pasting, thermal, morphological, rheological and structural characteristics of Chenopodium (Chenopodium album) starch. LWT - Journal of Food Science and Technology 66: 267274.

Jorge, N., A.C. da Silva, C.R. Malacrida. 2015. Physicochemical characterisation and radicalscavening activity of cucurbitaceae seed oils. Natural Product Research 29: 2313-2317.

Nakhon, P.P.S., K. Jangchud, A. Jangchud dan W. Prinyawiwatkul. 2017. Comparisons of physicochemical properties and antioxidant activities among pumpkin (Cucurbita moschata L.) flour and isolated starches from fresh pumpkin or flour. International Journal of Food Science Technology 52: 1-9.

Nkosi, C.Z., A.R. Opoku, S.E. Terblanche. 2006. Antioxidative effects of pumpkin seed (Cucurbita pepo) protein isolate in CCL4-induced liver injury in low-protein fed rats. Phytotherapy Research 20: 935-940.

Noelia, J.V, M.J. Mario Roberto, Z.M. José de Jesús and G.I. José Alberto. 2011. Physicochemical, technological properties, and health-benefits of Cucurbita moschata Duchense vs Cehualca [A Review]. Food Research International 44: 2587-2593.

Patel, S. 2013. Pumpkin (Cucurbita Sp.) Seeds As Nutraceutic: A Review on status quo and scopes. Journal of Nutrition and Metabolism 6: 183-189.

Quintana, S.E, R.M. Marsiglia, D. Machacon, E. Torregroza and L.A. García-Zapateiro. 2018. Chemical composition and Physicochemical properties of squash (Cucurbita moschata)

40 Anastasia Wheni Indrianingsih, Wuri Apriyana, Vita Taufika Rosyida, Khoirun Nisa, Septi Nurhayati, Cici Darsih 
cultivated in Bolivar Department (Colombia). Contemporary Engineering Sciences 11 1003-1012.

Rocha-Guzman, N.E., J.A., Gallegos-Infante, C.I. Delgado-Nieblas, J.J. Zazueta-Morales, R.F. Gonzalez-Laredo, V. Cervantes-Cardoza, F. Martinez-Bustos, A. Palazuelos. 2012. Effect of extrusion cooking on the antioxidant activity of extruded half product snacks made of yellow corn and pumpkin flours. International Journal of Food Engineering 8: $1-13$.

Wani, AA, I.A. Wani, P.R. Hussain, A. Gani, dan T.A. Wani. 2015. Physicochemical properties of native and $Y$-irradiated wild arrowhead (Sagittaria sagittifolia L.) tuber starch. International Journal of Biological Macromolecules 77: $360-368$.

Yadav, M., S. Jain, R. Tomar, G.B.K.S. Prasad, dan H. Yadav. 2010. Medicinal and biological potential of pumpkin: an updated review. Nutrition Research Reviews 23: 184-190. 